\title{
THE SIGNIFICANCE OF BUNGA TERUNG TATTOO FOR THE IBAN MEN IN JULAU, SARAWAK AND PUTUSSIBAU INDONESIA
}

\author{
Sonny Anak Jumpo ${ }^{1 *}$, Muhammad Puad Bin Bebit ${ }^{2}$ \\ 1Sonny Anak Jumpo, Universiti Malaysia Sabah, MALAYSIA, sonnyjumpo@gmail.com \\ 2Dr Puad Bin Bebit, Universiti Malaysia Sabah, MALAYSIA, cfuart@yahoo.com \\ ${ }^{*}$ Corresponding Author
}

\begin{abstract}
Bunga terung is a symbol synonymous with the Iban ethnic group in Borneo. This study is aimed to study the significance of bunga terung based on Ferdinand de Saussure's Linguistic Unit comprising of Sign, Signified and Signifier. In Borneo, the bunga terung is worn by Iban men who have attained puberty to signify entry into adulthood. There are varying practices on the sequence of application of the bunga terung between the Iban of Sarawak and Kalimantan. An interesting observation regarding the sequence is the time the bunga terung is received. In Sarawak, the isi ginti (fish hook) tattoo is worn first - pre-puberty, followed by the bunga terung, and the pantang rekung leher (neck tattoo) before other tattoos for the back and the legs. In Kalimantan, the bunga terung is not worn if the Iban male has not gone berjalai. This study discusses two findings; the significance of the bunga terung; and the sequence of its application on the Iban men from Sarawak.
\end{abstract}

Keywords: Iban tattooing, bunga terung, male rites of passage, semiotics, Iban Ethnic

\section{INTRODUCTION}

Tattooing is not a modern concept by any means. Body tattooing is an ancient practice going back millennia across Europe, Asia and Oceania. In ancient Britain, Celtic and Pictish warriors used woad, a blue dye that is now thought to have been used for full body tattoos. The discovery of an old "ice man" 5,300 years old was discovered in 1991 has the evidence to have a tattoo. It cannot be denied that the skills and craftsmanship are often outstanding. Take Borneo tattoos for example. Both men and women are found to sport intricate and beautiful tattoos on their bodies, denoting strength, achievements, spiritualism, and a deep sense of aesthetics all at once. Indeed, seeing an elderly Borneo tribe member today in tattooed glory is a magnificent sight to behold.

A unique rosette motif of Borneo deserves to be put under thorough investigation, and that is the bunga terung (eggplant flower). The bunga terung is a solid 8-petal motif that comes with 8 small sepals and an uncoloured spiral in the centre. Usually it is $13 \mathrm{~cm}$ in diameter and is worn on both shoulders of an Iban male before going for berjalai. Berjalai is Iban, and it is when men will journey to faraway places before returning back to their longhouse (Gomes, 1911). The bunga terung has become synonymous with Borneo tattoo, and tattoo enthusiasts the world over travel specifically to Borneo to be tattooed (by machine or traditional methods). The bunga terung is a unique work to deconstruct. As a rosette, the bunga terung does not appear to have any identifiable meaning - it is just a flower. But as a symbol, the bunga terung signifies a rite of passage of an Iban male. Here, the bunga terung is the signifier, and an Iban male having experienced berjalai is the signified.

\section{METHOD AND STUDY AREA}

Ferdinand de Saussure's theory of Semiotics unit of Sign, Signifier and Signified can be explained as thus: A 
Sign is comprised of a Signifier (word or image) and the Signified (mental concept from interpreting the Signifier). The relationship of the Signifier and Signified is subjective in nature, where the Signifier may produce varying forms of the Signified. In turn, the Signified meaning can be derived from varying forms of Signifiers. Imagine for example, a label on a bottle of organic honey. To encourage a mental picture of freshly harvested honey, the label shows a picture of a honey bee on a flower. To reinforce the mental picture, the label also has the words "freshly harvested organic honey". Both the illustration and the words are Signifiers for fresh organic honey, which is the intended mental picture to be Signified. Conversely, the words 'freshly harvested organic honey' could also bring up mental pictures of honeycombs and bee keepers in bee suits. Working together as whole, the Signifiers on the bottle label will have the Signified meaning of fresh organic honey, which in turn is a Sign of a quality product.

Word or image

What is evoked in the mind - mental concept

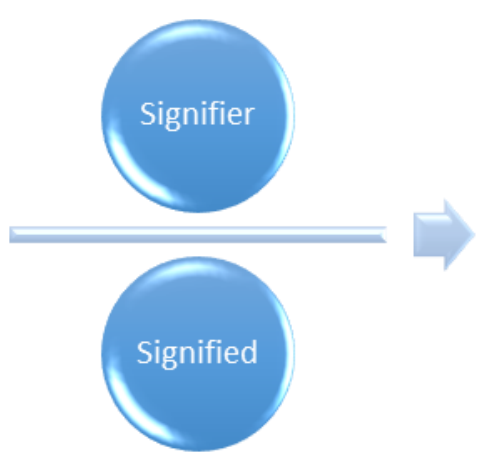

The meaning / message

that is communicated

Figure 1: Ferdinand De Saussure's Semiotics theory of Sign, Signifier and Signified (Saussure, 1959)

Through interviews with traditional tattoo artists and village elders from Kuching, Miri, Skrang, Julau, Teraja, Marudi, and Engkelili, it is revealed that most of the Sarawak Ibans have roots that can be traced back to Sungai Utik, West Kalimantan. This finding provided an opportunity to either debunk or confirm the findings regarding the Bunga Terung presented in these books ${ }^{1}$ on Borneo tattoos. To investigate the authenticity of the claims found in the books, a set of questions were constructed to be used on an expedition to Sungai Utik.

The main objective of the research is to enrich the information already available on Bunga Terung tattoo provided by many books so that the issue of misconception is addressed. At the same time, preserving the practical (practices that are not yet recorded) aspects of Iban tattoo culture by bringing them to the mainstream knowledge among the research community. Hence, the information generated from this study is significant in terms of enhancing greater understanding among the research community in the area of lban tattoo culture.

The questions were:

1. Nama reti pantang bungai terung? (What is the meaning of bunga terung tattoo?)

2. Berapa umur ke tau gagak pantang bungai terung? (At what age should one get the bunga terung tattoo?)

3. Nama pantang ke bukai enti ka bulih pantang ka urang Iban? (What kind of tattoo should one have if one wants to have Iban tattoo?).

\section{RESULTS AND DISCUSSION}

The bunga terung is given to an Iban male who is considered old enough to go through a certain rite of passage. This rite of passage is the berjalai, which means going on a journey to the next village. If we look at Saussure's theory of Sign, Signifier and Signified, the bunga terung Signifier is the black 8-petaled flower, and wearing it as a pair on both shoulders has the Signified meaning of going for berjalai. The bunga terung thus, is a Sign of an Iban male who is bujang (attained adulthood).

\footnotetext{
1 The Tattoo History Source Book (Gilbert, 2001); The History of Tattooing (Hambly, 2009); The Tattooing Arts of Tribal Women(Krutak, 2007); Basic Iban Design: an introduction(Ganjing, 1998); Pantang Iban(Jeroen Franken and Sven Torfinn, 1998); Head-Hunters: Black, White and Brown(Haddon, 1901); Ancient Ink: The Archaeology of Tattooing(Lars Krutak and Aaron Deter-Wolf, 2017); Using Ink to Channel Heritage(Hay, 2017)
} 


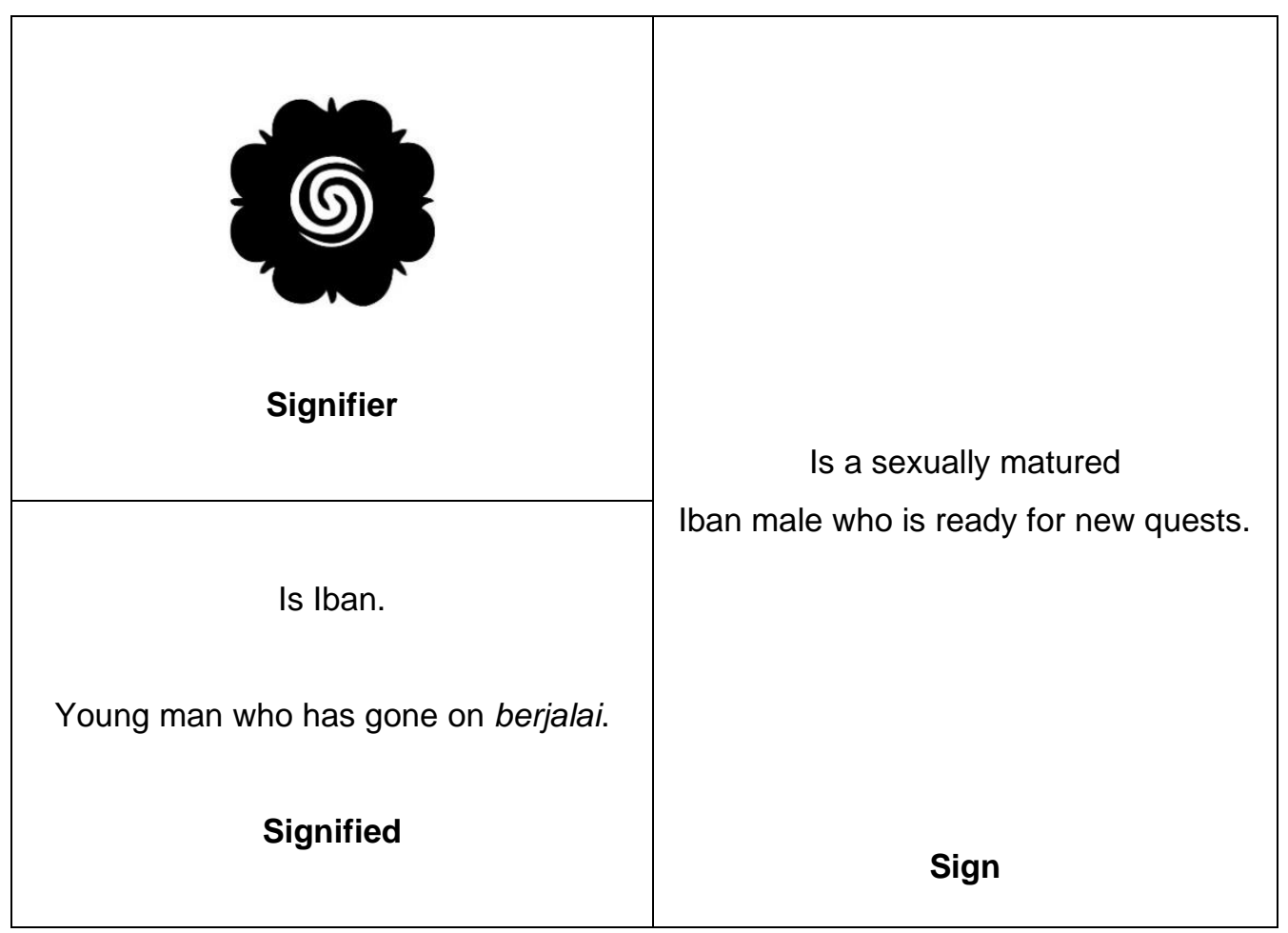

Figure 2: Bunga terung Sign, Signifier, and Signified.

The bunga terung comprises 3 elements - the petals, the sepals, and the double spiral. According to J.Franken and S. Torfinn (1998) the leaves vary number from 4 to 9 according to the size of the tattoo. Instead of the sepals, Franken and Torfinn said they are thorns placed in between the petals. The double spiral is located in the middle as the heart of the bunga terung, where Franken and Torfinn identified as the tali nyawa, or rope of life. According to Lars Krutak, the double spiral is a representation of the tadpole belly.

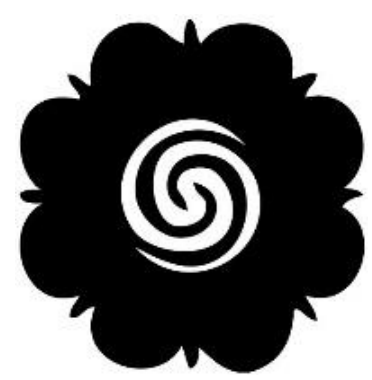

Figure 3: A common bunga terung design

Franken and Torfinn say that the bunga terung is the first tattoo a boy receives after circumcision, and is tattooed on the deltoid area of the shoulders. Its form is derived from the eggplant. Leaves vary in the number from four to nine according to the size of the tattoo. In between of each leaf, the tattoo artist may opt for the addition of thorns. The belly or heart of the flower displays a single or a double spiral whose inner ends may either meet or remain apart. The number and complexity of the windings of the spiral depend on the size of the tattoo and on the artist's skills. The spiral symbolizes a tadpole which represent initiation to manhood.

Interviews with members from the Sungai Utik and Sungai Saban longhouses and other Sarawakian tattoo artists reveal some common answers to the first question of 'What is the meaning of bunga terung tattoo?'. The answers all agree that getting the bunga terung is the rite of passage from a boy to adulthood. Right after attaining the bunga terung tattoo, the young man will start the process of berjalai. He is ready to go for an adventure and to walk to gain better understanding by completing a quest. Some longhouse inhabitants in Sungai Utik and Sungai Saban have no bunga terung tattoos. They did not berjalai. For them, it will be shameful to wear the bunga terung but did not berjalai. Sarawakian tattoo artists say that the bunga terung is the second tattoo for an Iban boy to receive, after the fish hook isi ginti. But the people of Sungau Utik and Sungai Saban say that the bunga terung is the third tattoo an Iban male will receive. Making the tattoo sequence to be: 1) Fish Hook isi ginti, 2) Neck Tattoo pantang rekung, and 3) bunga terung. 
Second question, 'Who is supposed to get the bunga terung tattoo? Male or Female?' The bunga terung wearer is to be male and it is located symmetrically on both shoulders. Going for 'berjalai' is also the process of looking for a suitable wife to live with. For an Iban male, 'berjalai' will mean visiting other long houses and communities, gaining more worldly knowledge and at the same time look for the best companion. According to the oldest interviewee of Sungai Utik, the bunga terung is for men, not for women. It will be not appropriate for a woman to berjalai. The most significant tattoo for women to have is pala tumpa, a series of zigzag lines encircling the forearms. The pala tumpa is a sign to show that the woman is good in mat weaving or basketry.

The third question is 'At what age should one get the bunga terung tattoo?' The answers were varied. There is no specific age number to get a bunga terung tattoo. Some said it is when an Iban boy reaches maturity or puberty at the ages of 10-15 years old. Others said it is when the boy is ready to move out or go for a quest. There were no definite answers for this question, as it differed long house to long house.

The last question is 'What Iban tattoo should one get if one wants to have an Iban tattoo?' This question focuses on important and significant lban tattoos that could be worn on the body. The isi ginti, or fish hook, on the calf is the first tattoo that a boy will receive, and it signifies that the boy can catch fish which metaphorically means that he can perform simple life skills. The pantang rekung is a neck tattoo and the second tattoo that a boy will receive, around the time of puberty. Once worn, the boy is believed to appear in the spiritual realm, and is visible to the spirits of their ancestors. The pantang rekung starts roughly 2 inches below the chin, covers the Adam's apple, and stops at the base of the neck. The design varies from longhouse to longhouse, and artist from artist. The third tattoo that a boy will receive is the bunga terung, when he is ready to berjalai. Along the journey which will now take the test of his life, the Iban male will be collecting arm, chest, back and leg tattoos.
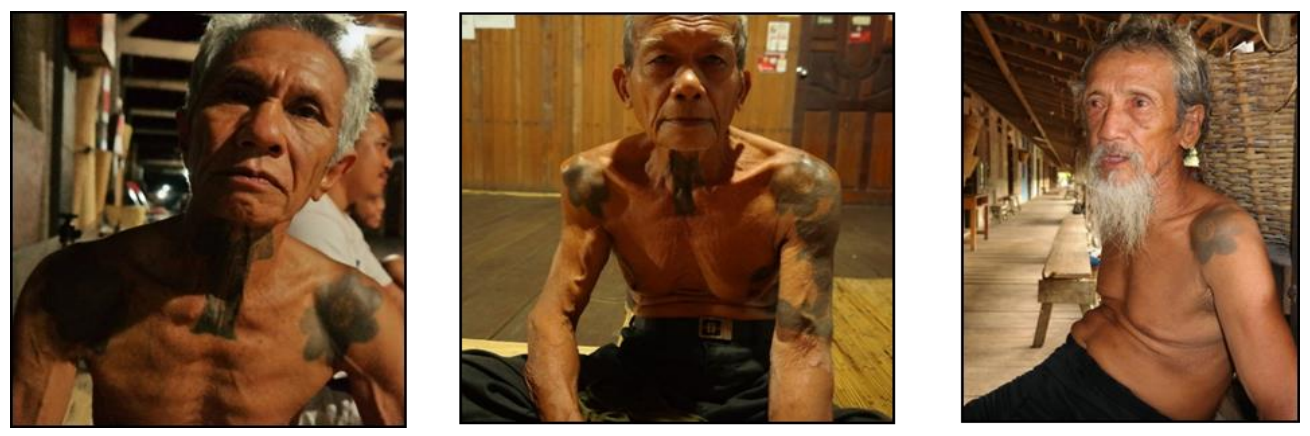

Iban Men with bunga terung tattoo
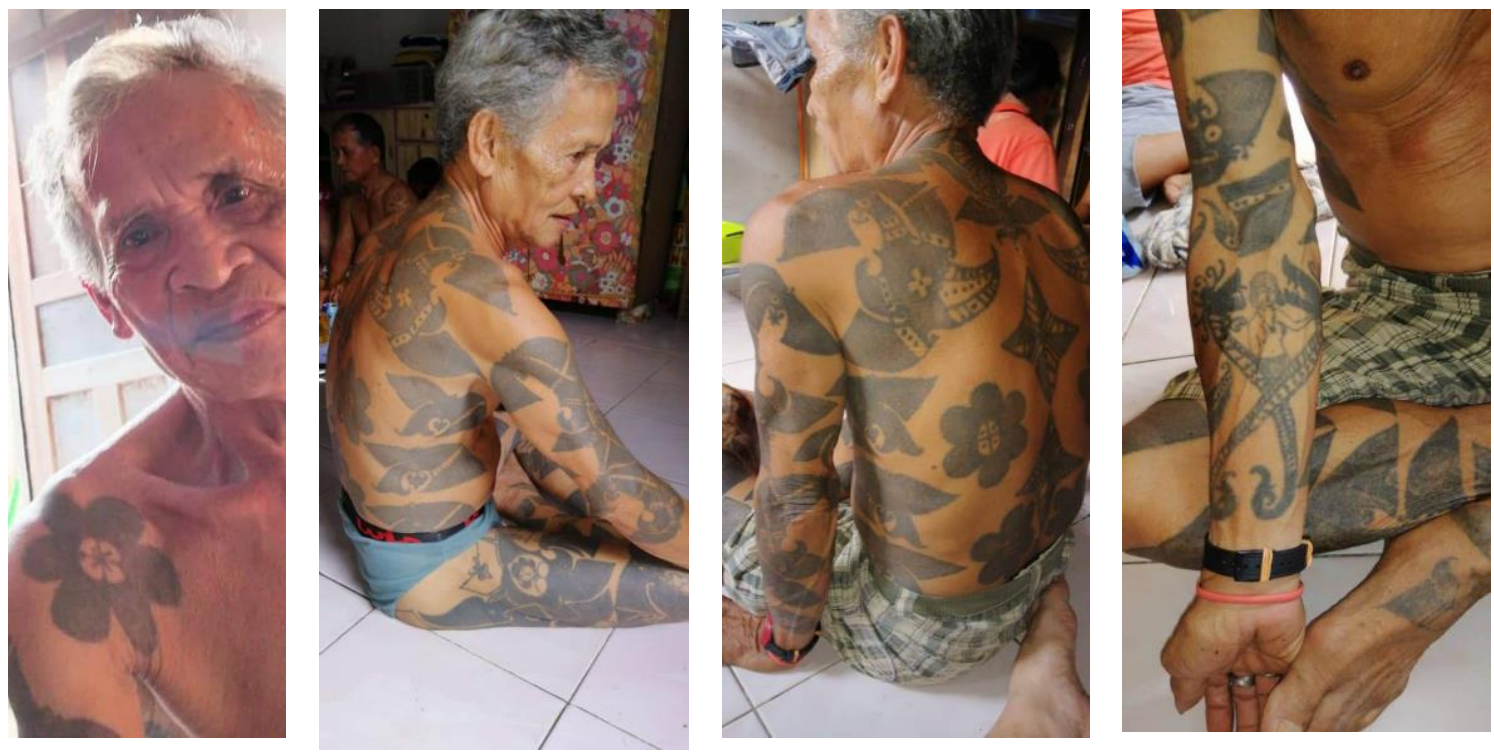

Flied trip to Julau,

Sarawak Malaysia 

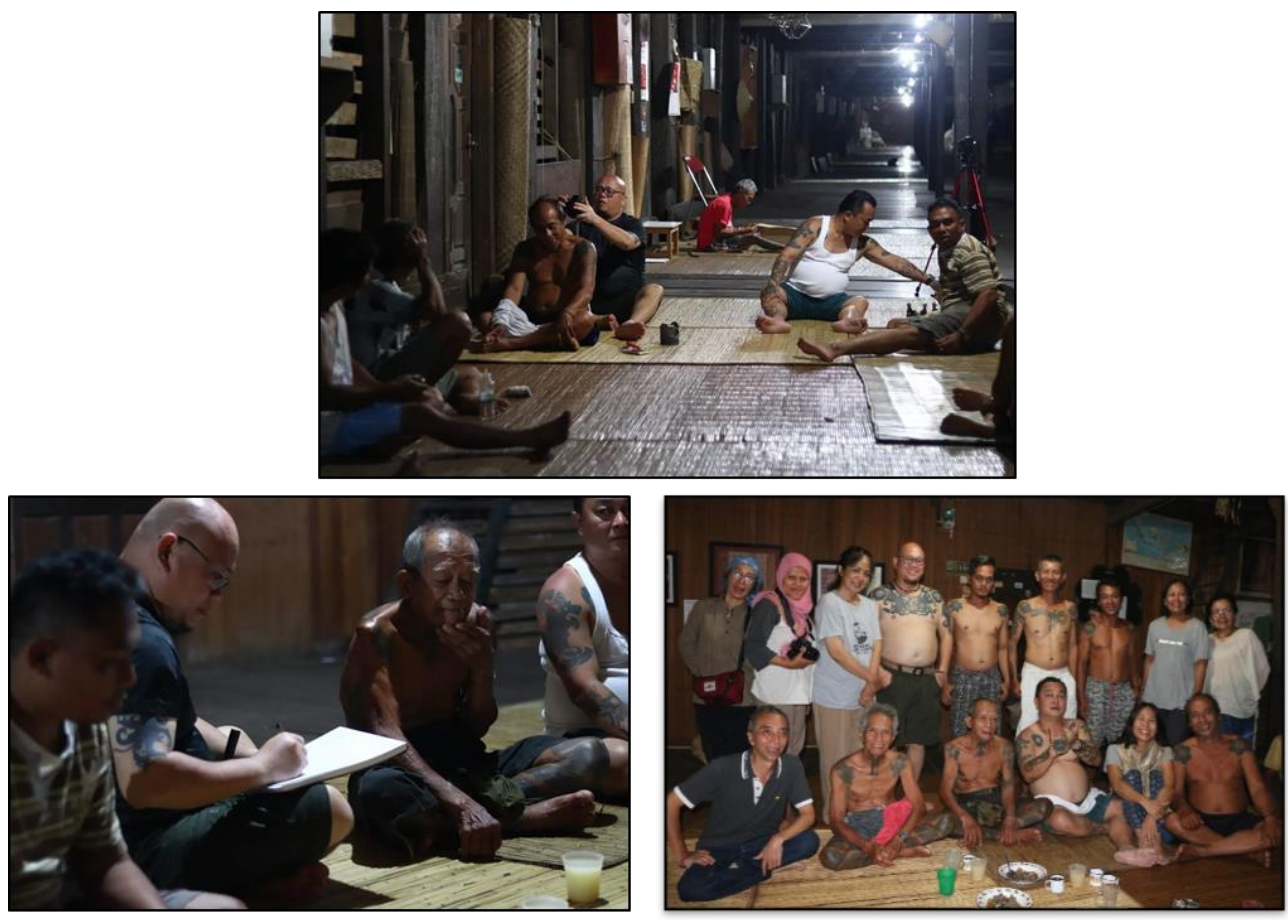

Flied trip to Sg Utik, Putussibau

Kalimantan Indonesia

\section{CONCLUSION}

An iban wearer of the bunga terung communicates to his community that he is sexually mature and is able to take care of himself. As such, he is also putting on display his readiness and eligibility to find a suitable companion or wife. In a way, the isi ginti, pantang rekung, and bunga terung act together as signifiers to carry the signified meaning that a particular iban male is in his prime, and is ready to start a family and provide for them. In this study, the deconstruction of the bunga terung has opened up many possibilities for other researchers of iban tattoo. As yet, there are no conclusive answers or evidence to confirm that the double spiral symbolically means rope of life, or that it is the intestinal coils of the tadpole. Varying accounts provide different explanations of the significance of the spiral, with some saying that it alludes to the circle of life, while other say that it has correlation with a boy becoming a man. Still, the bunga terung is a unique symbol that represents the Iban culture. For the wearer, it is akin to getting a badge for a new skill or achievement. The spiritual aspects of lban tattoos are not delved into in this research. The various motifs and symbols that make up the beauty of Iban tattoo is a treasure trove of mystical lore and spiritual beliefs. Replete with rituals that make up its unique cultural heritage and identity, the Iban tattoo culture merits deeper investigation and study.

\section{REFERENCE LIST}

Ganjing, A. A. (1998). Basic Iban design : an introduction. Dewan Bahasa dan Pustaka.

Gilbert, S. (2001). The Tattoo History Source Book. Juno Books.

Haddon, A. C. (1901). Head-Hunters: Black, White and Brown (Classic Reprint) (2018th ed.). Forgotten Books.

Hambly, W. D. (2009). The History of Tattooing. Dover Publications.

Hay, M. (2017). Using Ink to Channel Heritage. Retrieved September 20, 2009, from 
https://explorepartsunknown.com/borneo/using-ink-to-channel-heritage/

Jeroen Franken and Sven Torfinn. (1998). Pantang Iban. Typography \& Other Serious Matter.

Jumpo, S. (2013). Deconstruction of the Bunga Terung. Retrieved from https://dayakimpressions.wordpress.com/2013/01/02/deconstruction-of-the-bunga-terung/

Krutak, L. (2007). The Tattooing Arts of Tribal Women. Bennett \& Bloom.

Krutak, L. (2013). Lars' Tattoo. Retrieved September 29, 2019, from https://www.larskrutak.com/lars-tattoos/

Lars Krutak and Aaron Deter-Wolf. (2017). Ancient Ink: The Archaeology of Tattooing. University of Washington Pres.

Saussure, F. De. (1959). Course in General Linguistics (C. B. and A. Sechehaye, Ed.). Philosophical LLibrary. 